\section{Abstract}

As a type of virtual heritage, the development of Augmented Reality (AR) projects that intended to communicate the significance of architectural heritage requires evaluation to contribute to the field of both heritage and virtual heritage. This paper aims to define the role of evaluation for virtual heritage projects and contribute to this subject by discussing the case study of@Rkademi, which was held in December 2014, and the findings of the evaluation process. The findings reveal that although the evaluation process was not embedded with the application, participants benefited from the evaluation process, and it gave researchers feedback and the opportunity to enhance the application for the future.

öz

Bir sanal miras türü olarak mimari miras iletişimini amaçlayan Artırılmış Gerçeklik projeleri, hem miras alanına hem de sanal miras alanlarına katkı sağlamaları için bir değerlendirme sürecini gerektirmektedir. $\mathrm{Bu}$ çalışma değerlendirmenin sanal miras projelerinin geliștirilmesindeki rolünü ve bu alanda Aralık 2014'te gerçekleştirilmiş olan @ Rkademi örneğinin değerlendirme sürecini ve bulgularını sunarak katkıda bulunmayı amaçlar. Bulgular her ne kadar deneyimlere gömülü olmasa da değerlendirme sürecinin sergi katılımcılarına bağlamı aktarmada, geliștiriciler için ise uygulamayı geliștirme aracı ve fırsatı yarattığını göstermektedir.

Keywords: Augmented Reality, Evaluation, Virtual Heritage, Heritage Presentation

Anahtar Kelimeler: Artırılmış Gerçeklik, Değerlendirme, Sanal Miras, Miras Anlatımı

\title{
Evaluation of Augmented Reality Projects For The Dissemination of Heritage Information And The Case of @Rkademi
}

Tigin Töre

Mimar Sinan Güzel Sanatlar Üniversitesi, Mimarlık Fakültesi, Mimarlık Bölümï

Demet Binan

Mimar Sinan Güzel Sanatlar Üniversitesi, Mimarlık Fakültesi, Mimarlık Bölümü

Başvuru tarihi/Received: 23.01 .2018 , Kabul tarihi/Final Acceptance: 30.05 .2018

\section{INTRODUCTION}

Champion $(2015, p .181)$ proposes that the major aim for virtual heritage should be to "convey the unique significance of the simulated culture, which requires an attempt to understand how the original site was experienced and understood by its original inhabitants."

In terms of virtual reality, and particularly for augmented reality $(A R)$, the verb "to attempt" may have alternate meanings from different perspectives. For the user, it is an attempt to explore the medium, understand the interface and interpret the context; for the expert it is an attempt to convey significance and meaning consistently (within the scope of Nara document), effectively and transparently (regarding the London Charter (Beacham et al. 2009)). For the system developer it is an attempt to bring together software and hardware capabilities with the unique characteristics of heritage sites. It is also possible to add administrative, environmental and other contextual viewpoints into these perspectives. The interconnected multitude of these perspectives, caused by the continuous advancement of computational technologies, are changing the shape and understanding of the types of virtual realities.

While becoming more user friendly and commercially available, AR has been subject to both optimization and advances.
Platforms and tools (including both software and hardware capabilities) are under constant scrutiny and developers are still in search for a user experience that was described by researchers and pioneers decades ago. This makes it harder to craft an AR application for any purpose. Additionally, although there is literature evaluating AR environments, they generally focus on AR enabling technologies rather than exploring the human/user aspect of the projects, and they certainly do not consider the dissemination of information about cultural heritage. The quality of the content and dissemination is important in cultural heritage; therefore, for cultural heritage AR applications, evaluation has an important role. Additionally, continuous evaluations of virtual heritage projects contribute to creating more meaningful experiences that aim to communicate the significance of cultural heritage.

Because of the issues above, there is always a danger of previous work (including the ones that are given as examples) becoming outdated or irrelevant. This study aims to clarify how the function of evaluations and the inclusion of evaluation processes as a part of the experience can contribute the virtual heritage applications to better communicate heritage values and be more successful. The case study presented here is part of the $\mathrm{PhD}$ dissertation by the first author, Tigin Töre (2017). 


\section{EVALUATION OF VIRTUAL HERITAGE}

\section{The Aims of Virtual Heritage Projects}

Dünser and Billinghurst (2011), referring to both different modalities and engagement methods concerning different AR environments, as well as the different aims of the AR projects, point out the difficulties of developing a singular evaluation method. Therefore, they suggest an evaluation approach dependent on the questions posed.

Undoubtedly, the evaluation of AR applications that aim to communicate heritage requires this approach. While Dünser and Billinghurst (2011) lists potential methods of evaluation for AR, Champion (2011) classifies the evaluation methods available for virtual heritage applications as the following: expert testing (including guidelines), content and media comparison studies, physiological testing, task performance, surveys questionnaires and ethnographic evaluation. Champion's classification of evaluation methods of virtual modalities is proposed with heritage aims in mind and therefore includes a more interdisciplinary approach.

Another issue which must be addressed to create an evaluation process is the scale or specific aim of the project, which seems to correspond with the Dünser and Billinghurst's "question posed". Considering both the Burra and Ename Charters and the relevent literature, Pujol and Champion (2012) suggest six aims' for virtual heritage projects. While the first five of them are similar to charter principles, in their sixth aim they suggest that researchers "attempt to carefully evaluate its [the project's] effectiveness with above five aims in order to improve both the project and virtual heritage in general" (Pujol \& Champion 2012).

\section{Previous Research Examples}

The number of published research examples that focus on the evaluation of communication of heritage are quite few. The examples discussed below were chosen from this limited group for their selection of virtuality and evaluation methods.

\section{Palenque Project}

The Palenque Project is a virtual heritage project developed by Champion, Bishop and Dave (2012) in 2007. The project's research question was to understand the role of three interaction modes (instruction, observation and action) in cultural learning by task performance evaluation and without post-experience questionnaires. Although one aim of the research was to propose an evaluation without questionnaires, they had to include final questionnaires to compare the findings.

\section{AR-Cathedral}

AR-Cathedral is an AR application for the renaissance frescoes inside the gothic vaults of the Cathedral of Valencia; the project evaluation included expert review, physiological testing and questionnaires. The goal of the project was to visualize and disseminate the results of the terrestrial laser scanning prior to the dismantling of the Baroque vault, which existed from 1682 to 2006 (Portalés et al. 2009).

The AR-Cathedral application can be considered as one of the first examples of a virtual heritage project that included an AR evaluation. In this study, although a system evaluation carried out the assessments were about the AR enabling aspects (AR target size and types, ergonomics of the backpack etc.) rather than the information conveyed. However feedback about the heritage and suggestions to improve the contents of current application came from interviews with users.

\section{AR@Melaka Project}

The AR@Melaka project, tied to the Melaka heritage site, is a project that aimed to improve the visitor experience in AR environments; its evaluation methods included a task performance (a multiplechoice online test), questionnaires and on-site observations (Pendit et al. 2014).

At the site, researchers prepared a profile, multimedia content, maps and multiplechoice tests for predetermined information points. The profiles of the points included information such as name, function, year of construction, builder, and years of use.

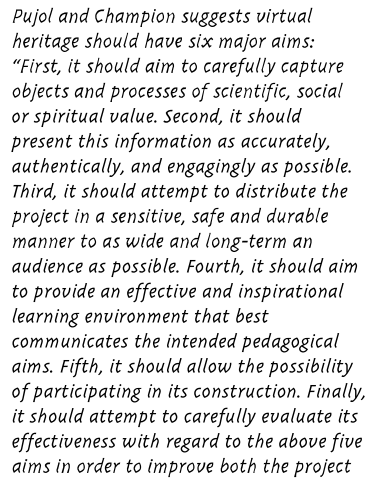
of participating in its construction. Finally, it should attempt to carefully evaluate its effectiveness with regard to the above five aims in order to improve both the project and virtual heritage in general." 
There were also multimedia presentations with content containing audio and video about the site. Furthermore, other interest points were indicated in relation to user's current position to facilitate navigation on the map. The multiple-choice test included a link to the online test page, where the prepared questions about the content were located.

The mobile AR application, which was created for this study, offered a very limited and one-way communication. AR view contains the tags of monuments that acts as the link of an html document about monuments. Even though users found navigating and accessing data easy, because of the heritage information was not spatialized, and limited interaction of the user interface, the question of whether if this is an AR application or not becomes an issue.

\section{EVALUATION: METHOD AND DATA}

@ Rkademi project's research question was to ascertain the effects of AR on the user's perspective on both the designed space and heritage content (Töre et al. 2014). For this purpose, researchers designed an evaluation that consisted of a questionnaire for participants; an expert review
Table: I

Demographic Data

\begin{tabular}{l|lll}
\hline 1a. & Age & No & $\%$ \\
\hline & Under 17 & 0 & 0 \\
& $17-25$ & 8 & 21,1 \\
& $25-35$ & 12 & 31,6 \\
& $36-50$ & 14 & 36,8 \\
& $50+$ & 4 & 10,5 \\
\hline $\mathbf{1 b}$. & Education & & \\
\hline A & High school & 7 & 18,4 \\
$\mathbf{A}$ & Graduate & 5 & 13,2 \\
$\mathbf{B}$ & Post graduate & 10 & 26,3 \\
$\mathbf{C}$ & PhD & 16 & 42,1 \\
\hline $\mathbf{1 c .}$ & Occupation (multiple answers possible) & & \\
\hline & Graduate student (architecture) & 6 & 15,8 \\
& Graduate student (other) & 1 & 2,6 \\
& Post-graduate student & 9 & 23,7 \\
& Instructor & 30 & 78,9 \\
& Architect/interior arch. & 26 & 68,4 \\
& Conservation specialist & 6 & 15,8 \\
& Urban planner & 2 & 5,3
\end{tabular}

panel also evaluated the experience. The expert review panel was composed of scholars who were conservation specialist and medium experts, and the panel reviewed the application and the experience.

\section{User Evaluation Questionnaire}

The questionnaire had five sections: demographic information, previous experiences with AR, the evaluation of the experience, the value of the contribution of AR to the experience and thoughts on current conservation issues. Apart from the demographic section, the questionnaire used Likerd scaling - 1 (lowest) to 5 (highest) — for qualitative measurements. Sections include also multiple choice questions and a multiple answer question (5c). The results were organised by these types rather than the relevant section for easier data representation (Tables 2 and 3).

The questionnaire was conducted during the exhibition in the Mimar Sinan Fine Arts University (MSFAU) Findiklı campus. The questionnaire language was Turkish. Although around 120 visitors received the questionnaire, only 38 were returned, mostly from scholars and instructors. Participants' responses to specific age, education and occupation groups were examined together and comparatively.

Looking at the demographic results (Table 1), we see that the majority of the participants have at least a graduate level education and are professionally related to the space (e.g., jobs as architect/interior architect). This profile of users was expected, as the exhibition was held in the architecture faculty; therefore, the evaluation questions were prepared with this expectation in mind.

It is possible to group the participants as follows: 12 undergraduate and graduate students (group A), $10 \mathrm{PhD}$ candidates (group $B$ ) and 16 post-PhD scholars (group $C$ ).

The second section aims to find the participants knowledge and prior experiences of the AR and related technologies. The third and fourth sections of the questionnaire was designed to ascertain the participants' perception of the infor- 


\begin{tabular}{|c|c|c|c|c|c|c|}
\hline 2 & Previous Virtual Experiences & 1 & 2 & 3 & 4 & 5 \\
\hline $2 e$. & Did you have any difficulties viewing AR environment?" & $\begin{array}{l}0 \\
(\% 0)\end{array}$ & $\begin{array}{l}0 \\
(\% 0)\end{array}$ & $\begin{array}{l}9 \\
(\% 23,7)\end{array}$ & $\begin{array}{l}16 \\
(\% 42,1)\end{array}$ & $\begin{array}{l}13 \\
(\% 34,2)\end{array}$ \\
\hline $2 f$ & $\begin{array}{l}\text { Would you like to use this kind of application to be } \\
\text { informed about your surroundings? }\end{array}$ & $\begin{array}{l}0 \\
(\% 0)\end{array}$ & $\begin{array}{l}1 \\
(\% 2,6)\end{array}$ & $\begin{array}{l}2 \\
(\% 5,3)\end{array}$ & $\begin{array}{l}7 \\
(\% 18,4)\end{array}$ & $\begin{array}{l}28 \\
(73,7)\end{array}$ \\
\hline 3 & User's Evaluation of AR experience & & & & & \\
\hline $3 a$. & Are you satisfied with the exhibition? & $\begin{array}{l}0 \\
(\% 0)\end{array}$ & $\begin{array}{l}0 \\
(\% 0)\end{array}$ & $\begin{array}{l}5 \\
(\% 13,2)\end{array}$ & $\begin{array}{l}14 \\
(\% 36,8)\end{array}$ & $\begin{array}{l}19 \\
(\% 50)\end{array}$ \\
\hline $3 c$. & Did you read the supplementary information? & $\begin{array}{l}1 \\
(\% 2,6)\end{array}$ & $\begin{array}{l}7 \\
(\% 18,4)\end{array}$ & $\begin{array}{l}6 \\
(15,8)\end{array}$ & $\begin{array}{l}16 \\
(\% 42,1)\end{array}$ & $\begin{array}{l}7 \\
(\% 18,4)\end{array}$ \\
\hline $3 d$. & Did you listen to the audio narrative? & $\begin{array}{l}7 \\
(\% 18,4)\end{array}$ & $\begin{array}{l}9 \\
(\% 23,7)\end{array}$ & $\begin{array}{l}6 \\
(\% 15,8)\end{array}$ & $\begin{array}{l}8 \\
(\% 21,1)\end{array}$ & $\begin{array}{l}7 \\
(\% 18,4)\end{array}$ \\
\hline $3 e$. & Did the experience affect your view of space? & $\begin{array}{l}1 \\
(\% 2,6)\end{array}$ & $\begin{array}{l}0 \\
(\% 0)\end{array}$ & $\begin{array}{l}6 \\
(\% 15,8)\end{array}$ & $\begin{array}{l}10 \\
(\% 26,3)\end{array}$ & $\begin{array}{l}21 \\
(\% 55,3)\end{array}$ \\
\hline $3 f$. & $\begin{array}{l}\text { Did the exhibition make you want to study or become more } \\
\text { informed about this space? }\end{array}$ & $\begin{array}{l}2 \\
(\% 5,3)\end{array}$ & $\begin{array}{l}2 \\
(\% 5,3)\end{array}$ & $\begin{array}{l}6 \\
(\% 15,8)\end{array}$ & $\begin{array}{l}14 \\
(\% 36,8)\end{array}$ & $\begin{array}{l}14 \\
(\% 36,8)\end{array}$ \\
\hline 4 & Contribution of AR Experience to User & & & & & \\
\hline $4 a$. & Were you given enough information? & $\begin{array}{l}0 \\
(\% 0)\end{array}$ & $\begin{array}{l}1 \\
(\% 2,6)\end{array}$ & $\begin{array}{l}5 \\
(\% 13,2)\end{array}$ & $\begin{array}{l}15 \\
(\% 39,5)\end{array}$ & $\begin{array}{l}17 \\
(\% 44,7)\end{array}$ \\
\hline $4 b$. & Was the navigation sufficient/easy to follow? & $\begin{array}{l}0 \\
(\% 0)\end{array}$ & $\begin{array}{l}7 \\
(\% 18,4)\end{array}$ & $\begin{array}{l}8 \\
(\% 21,1)\end{array}$ & $\begin{array}{l}10 \\
(\% 26,3)\end{array}$ & $\begin{array}{l}12 \\
(\% 31,6)\end{array}$ \\
\hline $4 c$. & Was the exhibition's scope satisfactory? & $\begin{array}{l}0 \\
(\% 0)\end{array}$ & $\begin{array}{l}1 \\
(\% 2,6)\end{array}$ & $\begin{array}{l}2 \\
(\% 5,3)\end{array}$ & $\begin{array}{l}22 \\
(\% 57,9)\end{array}$ & $\begin{array}{l}13 \\
(\% 34,2)\end{array}$ \\
\hline $4 d$. & $\begin{array}{l}\text { Did you feel a sense of exploration (about the space or the } \\
\text { medium)? }\end{array}$ & $\begin{array}{l}0 \\
(\% 0)\end{array}$ & $\begin{array}{l}2 \\
(\% 5,3)\end{array}$ & $\begin{array}{l}0 \\
(\% 0)\end{array}$ & $\begin{array}{l}11 \\
(\% 28,9)\end{array}$ & $\begin{array}{l}25 \\
(\% 65,8)\end{array}$ \\
\hline $4 f$. & $\begin{array}{l}\text { Would you like to use this medium for other purposes } \\
\text { (informational or other)? }\end{array}$ & $\begin{array}{l}0 \\
(\% 0)\end{array}$ & $\begin{array}{l}3 \\
(\% 7,9)\end{array}$ & $\begin{array}{l}5 \\
(\% 13,2)\end{array}$ & $\begin{array}{l}6 \\
(\% 15,8)\end{array}$ & $\begin{array}{l}24 \\
(\% 63,2)\end{array}$ \\
\hline 5 & Thoughts On Current Conservation Issues of the Heritage & & & & & \\
\hline $5 a$. & $\begin{array}{l}\text { Given the entire history of site, do you think it is necessary } \\
\text { to conserve past renovations? }\end{array}$ & $\begin{array}{l}1 \\
(\% 2,6)\end{array}$ & $\begin{array}{l}0 \\
(\% 0)\end{array}$ & $\begin{array}{l}2 \\
(\% 5,3)\end{array}$ & $\begin{array}{l}10 \\
(\% 26,3)\end{array}$ & $\begin{array}{l}24 \\
(\% 63,2)\end{array}$ \\
\hline $5 e$. & $\begin{array}{l}\text { To what extent did the exhibition affect your opinions } \\
\text { while answering the above questions? }\end{array}$ & $\begin{array}{l}1 \\
(\% 2,6)\end{array}$ & $\begin{array}{l}7 \\
(\% 18,4)\end{array}$ & $\begin{array}{l}7 \\
(\% 18,4)\end{array}$ & $\begin{array}{l}13 \\
(\% 34,2)\end{array}$ & $\begin{array}{l}10 \\
(\% 26,3)\end{array}$ \\
\hline $5 f$. & $\begin{array}{l}\text { Is this medium useful to you when forming your opinions } \\
\text { in a setting? }\end{array}$ & $\begin{array}{l}0 \\
(\% 0)\end{array}$ & $\begin{array}{l}1 \\
(\% 2,6)\end{array}$ & $\begin{array}{l}3 \\
(\% 7,9)\end{array}$ & $\begin{array}{l}8 \\
(\% 21,1)\end{array}$ & $\begin{array}{l}26 \\
(\% 68,4)\end{array}$ \\
\hline
\end{tabular}

mation communicated by the experience. The process of perception is quite relative for every person; trying to understand the level of it can also result in ambiguous conclusions. Therefore, to determine a level of perception it is necessary, at minimum, to ask participants if they listened to narration, read the supporting posters and banners and completed the tour. Their answers to these questions also contributed to our assessment of the participants' level of satisfaction and the quality of the overall experience.

The fifth and final section of the questionnaire was about the participants' views on issues of conservation, and it queried whether the scenarios helped them to shape these views. The corresponding answers support the view that all the layers of heritage should be conserved, and the
Table:2

Likerd Scale Questions and Data [Translated from the original Turkish questionnaire] 


\begin{tabular}{|c|c|c|c|}
\hline & & NO. & $\%$ \\
\hline \multirow[t]{5}{*}{$2 a}$. & Device ownership (plural mc) & & \\
\hline & Mobile Phone & 35 & 92,1 \\
\hline & Tablet PC & 18 & 47,4 \\
\hline & Wearable Computer & 1 & 2,6 \\
\hline & Other & 0 & 0 \\
\hline \multirow[t]{3}{*}{$2 b}$. & Have you previously experienced an AR environment? & & \\
\hline & Yes & 9 & 23,7 \\
\hline & No & 29 & 76,3 \\
\hline \multirow[t]{3}{*}{$2 c}$. & Have you previously experienced an AR-like environment & & \\
\hline & Yes & 15 & 23,7 \\
\hline & No & 23 & 60,5 \\
\hline \multirow[t]{5}{*}{$2 d}$. & Which device did you use for the experience? & & \\
\hline & iOS Smartphone & 16 & 42,1 \\
\hline & iOS Tablet & 1 & 2,6 \\
\hline & Android Smartphone & 18 & 47,4 \\
\hline & Android Tablet & 0 & 0 \\
\hline \multirow[t]{6}{*}{$3 b}$. & How many experience points have you visited?(out of 25) & & \\
\hline & Less Than 5 & 2 & 5,3 \\
\hline & $5-10$ & 9 & 23,7 \\
\hline & $10-15$ & 8 & 21,1 \\
\hline & $15-20$ & 11 & 28,9 \\
\hline & $20-25$ & 7 & 18,4 \\
\hline \multirow[t]{6}{*}{$3 g}$. & Which theme of experience was your favourite or informat & possil & \\
\hline & Previous states of buildings & 24 & 63,2 \\
\hline & Previous states of the building environment & 2 & 5,3 \\
\hline & Renovation of 1970 & 5 & 13,2 \\
\hline & Sketches & 5 & 13,2 \\
\hline & The comparative display of prior 1974 and today & 17 & 44,7 \\
\hline \multirow[t]{5}{*}{ 4e. } & How often should this exhibit be displayed? & & \\
\hline & Once & 1 & 2,6 \\
\hline & At regular intervals & 10 & 26,3 \\
\hline & Continuous & 27 & 71,1 \\
\hline & Should not be done & 0 & 0 \\
\hline \multirow[t]{5}{*}{5 b. } & How would you define this structure? & & \\
\hline & A palace from the 19th. century & 4 & 10,5 \\
\hline & A Modernist architectural example & 8 & 21,1 \\
\hline & A waterfront university campus & 5 & 13,2 \\
\hline & All of above & 20 & 52,6 \\
\hline
\end{tabular}




\begin{tabular}{|c|c|c|c|}
\hline 5c. & $\begin{array}{l}\text { How would you sort the below statements according to their importance (1 important - } 4 \\
\text { unimportant) }\end{array}$ & & $\begin{array}{l}\text { Average } \\
\text { over } 4\end{array}$ \\
\hline & The floors are made of wood & & 2,2 \\
\hline & The light wells were added in 1970 & & 2,5 \\
\hline & The Entrance Hall (Mimar Sinan Hall) was elevated in 1970 & & 2,5 \\
\hline & There were designs in the wooden structure & & 2,7 \\
\hline \multirow[t]{4}{*}{ 5d. } & What should be the conservation approach of these structures? & & \\
\hline & The building should be preserved in it's initial (palace) state & 5 & 13,2 \\
\hline & The building should be preserved in the state of its 20 th -century interventions & 13 & 34,2 \\
\hline & Every aspect of previous states of the building should be considered and conserved & 20 & 52,6 \\
\hline
\end{tabular}

@ R Rademi environment was considered as a valued way to represent the previous architectural states.

The questionnaire contained multiplechoice, plural multiple-choice and openended questions. The multiple-choice questions in Section 5 provoked participants to think about the conservation of the heritage and to evaluate the role of the relevant experience.

\section{@RKADEMI PROJECT}

The Cemile and Munire Sultan Palaces seem to occupy a small place when all the cultural history of Istanbul is considered, but they have stood witness to many important political and social developments since they were built in 1859 .

As an educational institution, Mimar Sinan Fine Arts University, the oldest art institution in Turkey, has a history of 133 years; it started as Imperial Fine Arts School (Mekteb-i Sanayi-i Nefise-i Şahane), and now includes these two structures. This project was an effort to digitally embed

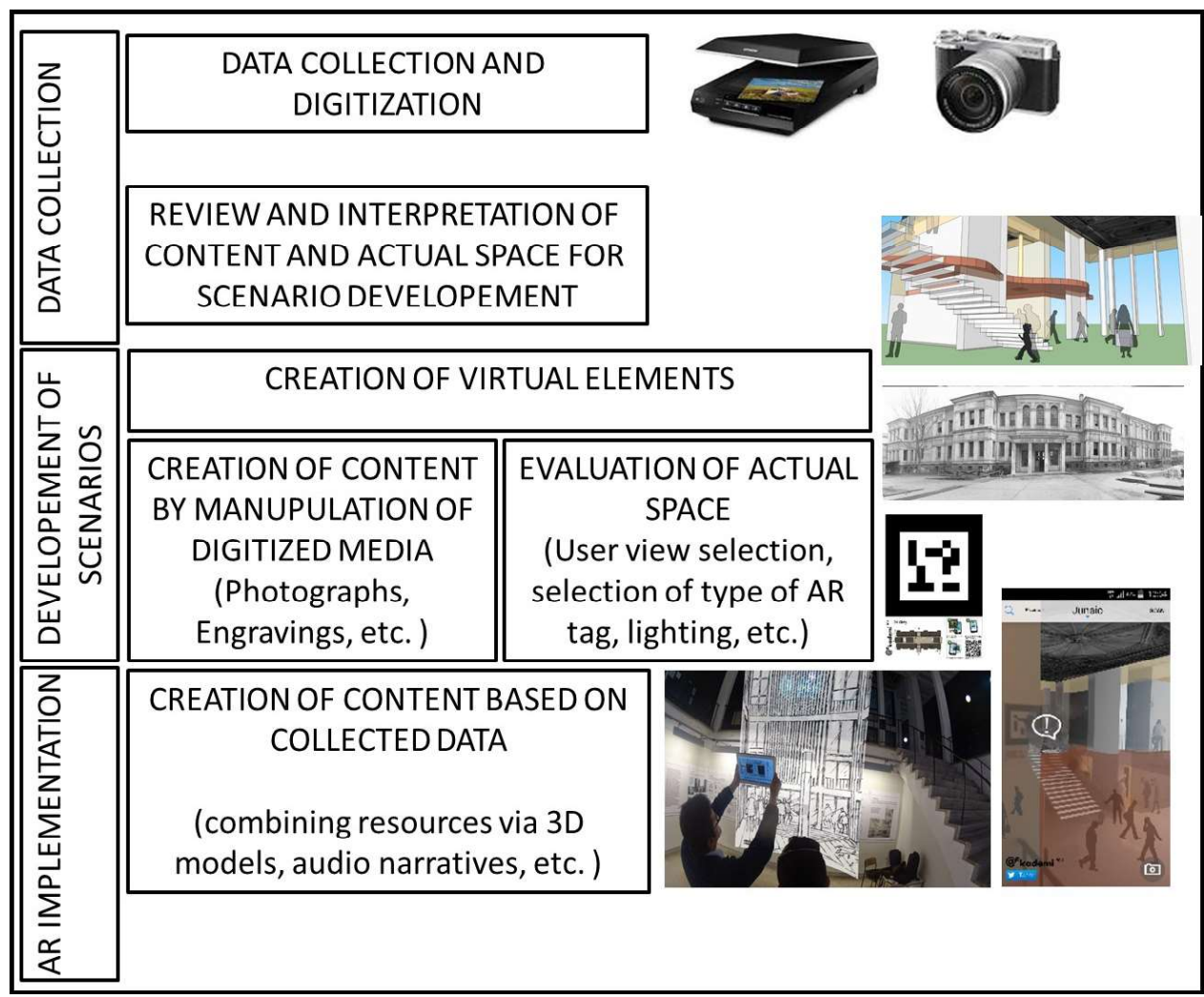

Figure: I

CreationWorkflow for @Rkademi

Project 


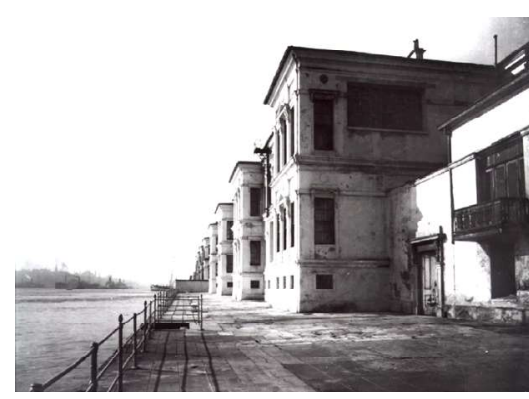

Figure: 2

Cemile Sultan Palace seaside façade (photographs ${ }^{2}$ from 1940's, after the fire, after the renovation and current state)
Figure: 3

Entrance of MSFAU Findikli Campus, (photographs from before 3 (below) the renovation and current state (above))
2 Courtesy of Mimar Sinan Fine Arts University Photography Studio

3 Courtesy of Mimar Sinan Fine Arts University Photography Studio the historical strata of these university buildings by me ans of AR into the day-to-day life of the campus. The goal in communicating these historical layers was for users to perceive the intrinsic value of this architectural heritage.

In order to include these different historical layers, the previous functions of the buildings of the Mimar Sinan Fine Arts University Findiklı Campus and the spatial impacts of these changes were researched in the archives and gathered from previous projects. Using the information we gathered, we were able represent the significant architectural changes in augmented reality scenarios and turned those into AR experiences within the @ Rkademi AR exhibition.

The exhibition took place at the MSFAU Findıklı Campus between 17 November and 31 December 2014. This date was chosen for the availability of the space and the relative high user density around these dates. Although total visitation time was dependent on the users' interest and the walking distance between the points of interests, the total duration of visiting the

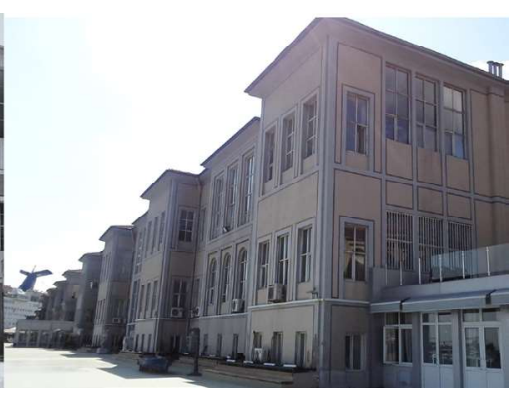

exhibition was around thirty minutes.

@Rkademi contains data about the buildings in different points of time, which was gathered from books, university archives and other works about the buildings. The data was classified according to both time and place, and then we created twenty scenarios to cover the life span of the buildings and their environment, up to the present day. The data we found also included a social narrative of the Mimar Sinan Fine Arts University Findıklı Campus, which was previously named the State Academy of Fine Arts; the social narrative tells another story, of the campus's intangible heritage, which covers more than 120 years of education in fine arts and architecture.

To create the AR environment, the Metaio AR design environment was used (Metaio Creator, Junaio, Metaio Toolbox, etc.). Using this AR environment also made it possible for us to develop the experience in both Android and iOS platforms, which was essential for reaching a broader audience with a familiar interface. The 3D reconstructions were made in Trimble's

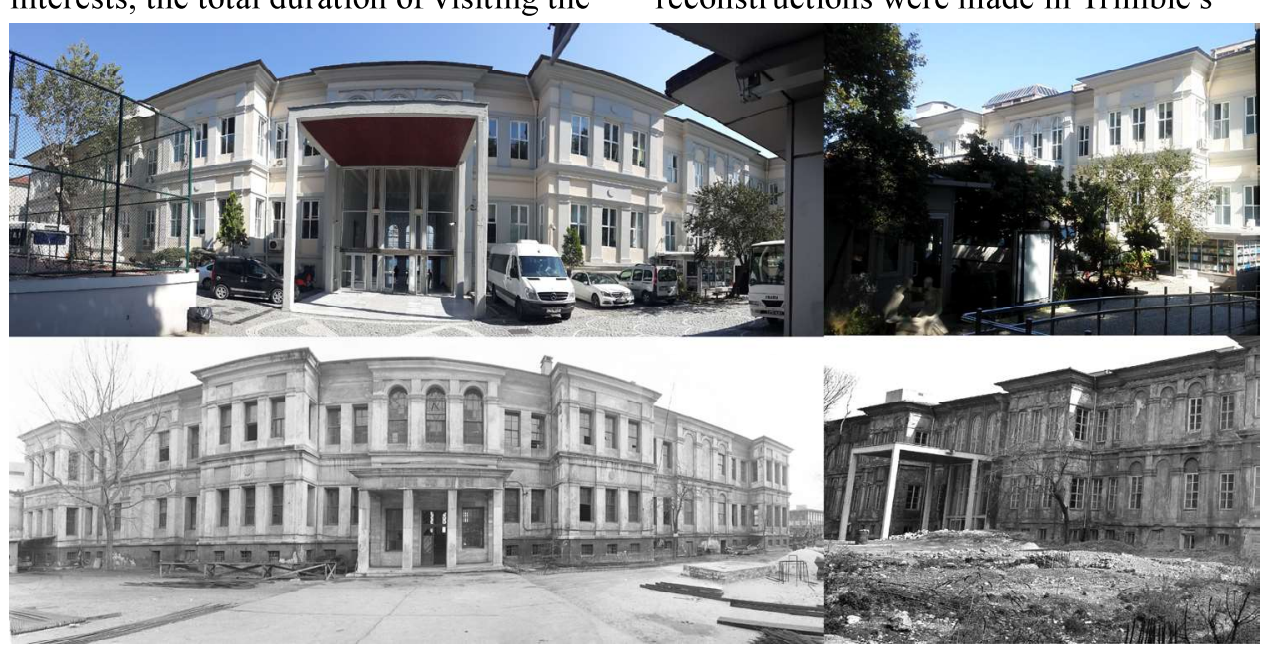



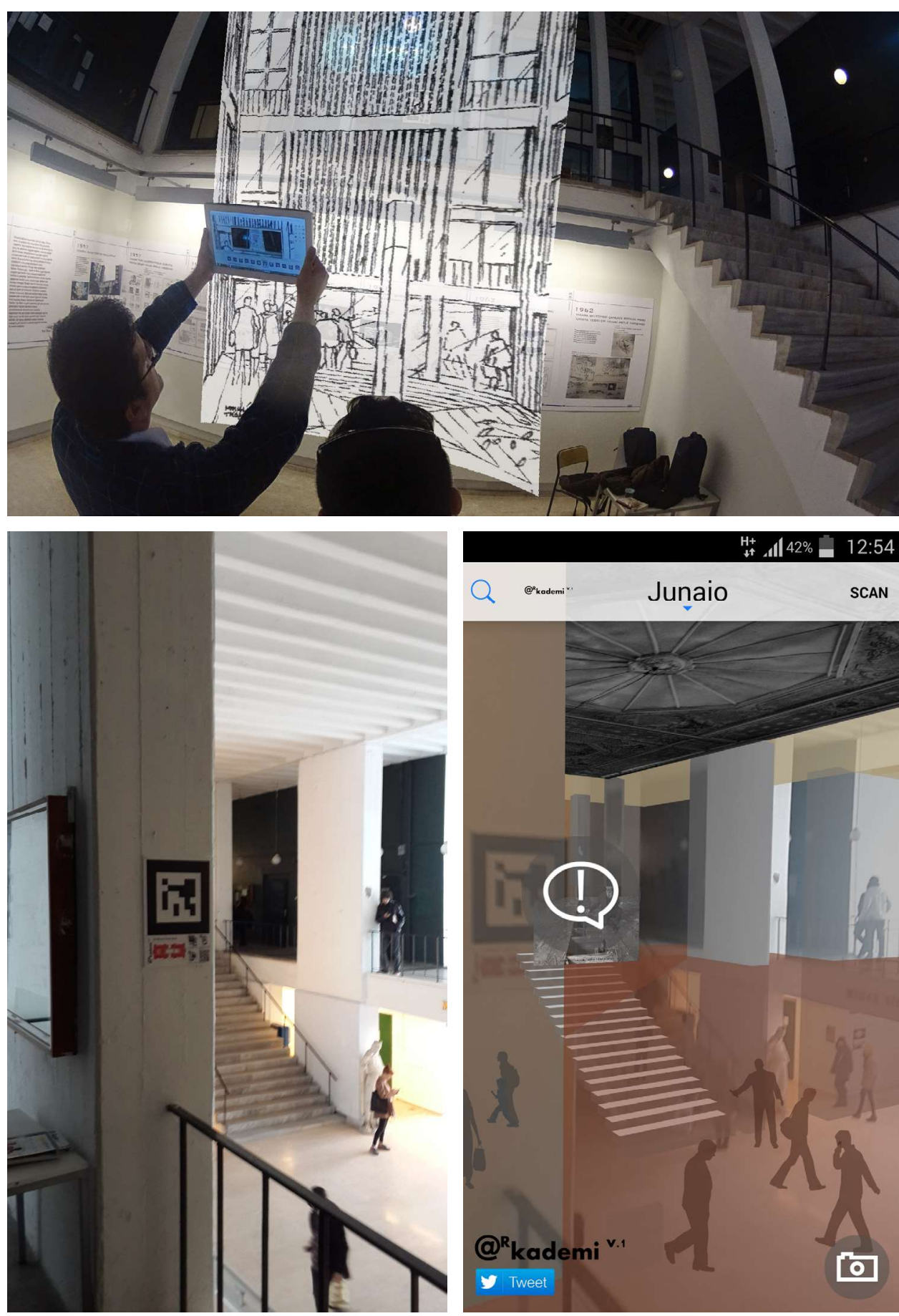

SketchUp and converted to a supported, $3 \mathrm{D}$ representation format. Other software used to manipulate images include Adobe Photoshop, Autodesk AutoCAD and Kubit/PhoToPlan. Also, audio narratives were added to enhance the experience.

Although the Metaio AR design environment contains many options for

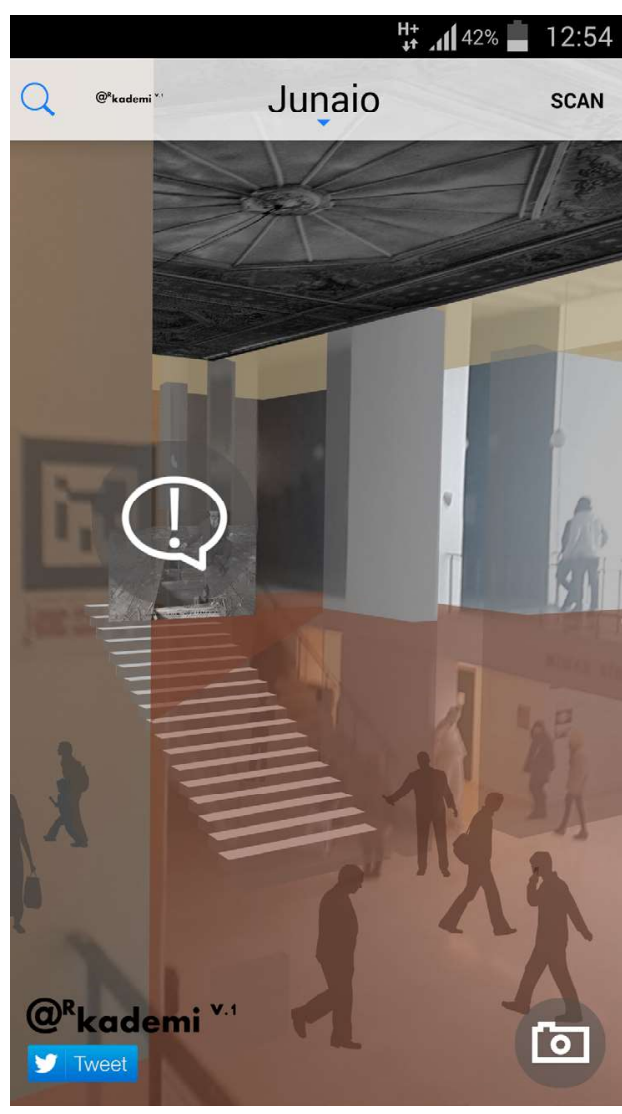

developing an AR experience and is robust enough to do so (when compared to industry standards), AR development requires experience in coding and data manipulation and understanding the attributes of the spaces (changes in daylight, color, shapes, size, etc.). Choosing the right trackable type for AR environments proved to be
Figure: 4

Representation of User's AR experience
Figure: 5

Physical space and Augmented Space samples of @Rkademi AR experience 
Figure: 6

Example views from different experiences

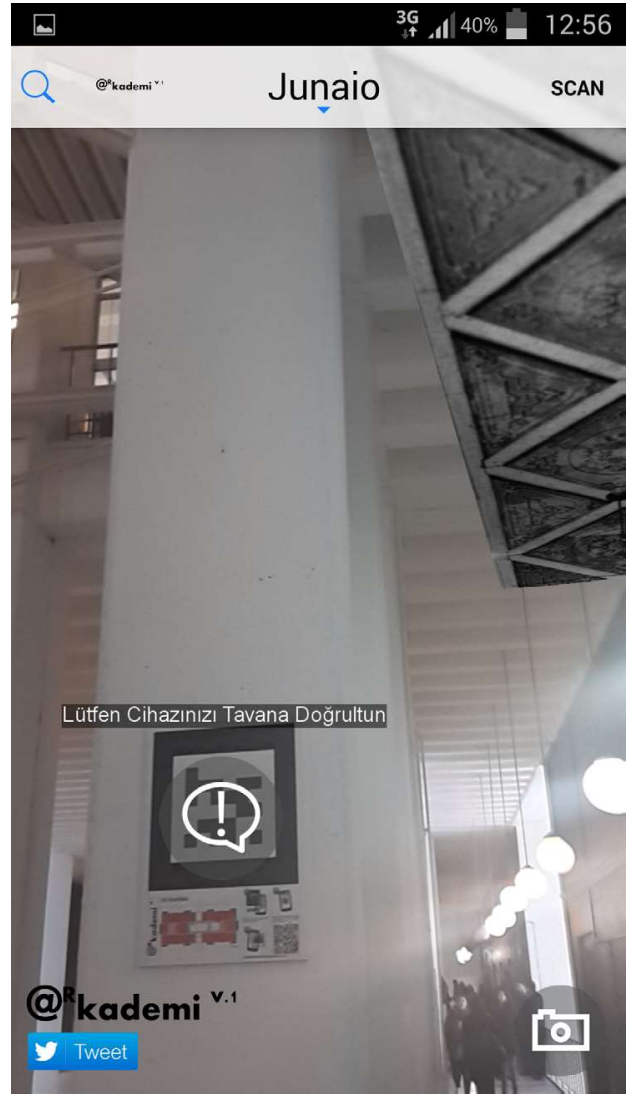

a bigger problem than expected. Most significantly, as stated in AR Cathedral Project the properties of light changed through the day, and the changing interior lighting made it difficult to create visual trackables. Therefore, we used a rather conventional method of image tracking, which also served as a hint to the visitor that an AR experience was available.

\section{EVALUATIONOF@RKADEMI}

\section{Results of Questionnaire Evaluation Previous AR Experience}

Although the participants' smart device ownership was very high, only $23,7 \%$ of the users had previously encountered AR environments. Participants' use of ARand VR-like environments was 39,7\%. According to these results, it is possible to say that some of the participants had prior knowledge of, or interest about, the medium. On the other hand, considering the wide use of navigation software on portable platforms and the (assumed) spatial interests of the participants, the result was lower than expected.

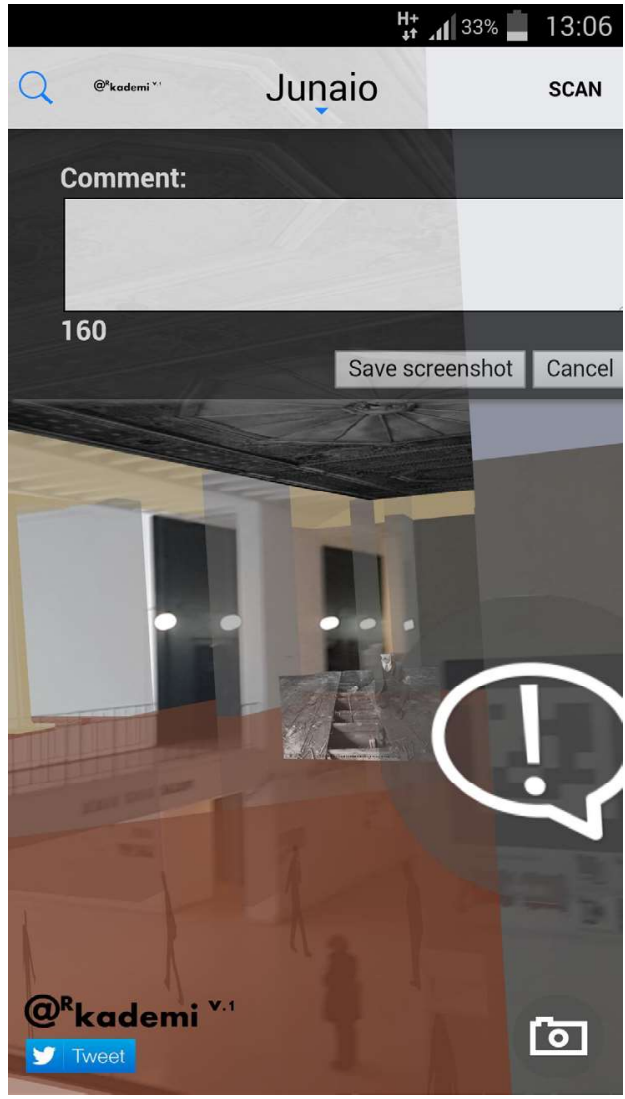

The participants' responses to the question evaluating the usability (ease of use) of the application was 4,1 (out of 5). This result had a uniform distribution across groups A, B and C. When assessed together, the lack of familiarity with AR experiences that was identified in previous question and the result of this usability question reveal that the application is more useful than the participants expected.

Although the AR environment was new to most of the participants, the replies to question $2 \mathrm{f}$ - "Would you like to use this kind of application to be informed about your surroundings?"-were quite positive (4,7 out of 5). This positive attitude might reflect the viewpoint known as "high-tech perception," but a positive view of AR can also be attributed to the excitement and sense of discovery created by this spatial experience. It is worth noting that iOS users gave an average rating of 4,3 , but the average for Android platform users was 5,0 ; this was the only question that elicited a different response based on operating platform. 


\section{The User's Evaluation of the AR Experience}

Sixty percent of the participants indicated that they read the printed material (posters and brochures), which, in the context of an AR environment, would normally be considered a high rate. However, we consider the average rate, 3,6 , to be low in the context of presenting important historical and heritage information. In parallel to this finding, the responses regarding the usage of audio narratives were similarly low (3 out 5 ).

Another indicator for measuring the level of engagement with and influence of the experience is participants' completion rate of the exhibition scenarios. Although this is a quantitative question, we found that the responses were qualitative and that participants considered this question (3b) as an evaluation of the content, as the results were evenly dispersed between 5 to 25 scenarios. Therefore, the navigation between the points of experience was not adequate (it was only available on printed media), and it should have been inserted into the experience as related points.

\section{The Contribution of the AR Experience to the User}

The questions in this section were meant to explore the successes and failures of cultural information communication and provide clearer information on performance. The users, who we can assume have an opinion about the buildings they are in, were simultaneously given implicit information via both the AR environment and the physical buildings. They expressed increased feelings of both exploration and curiosity (4,3 out of 5$)$. Parallel to this, the responses to question $3 \mathrm{f}$ - the need to obtain more information about the architectural heritage-were similarly high $(3,9$ out of 5).

For question $4 \mathrm{a}$, visitors replied that they were given enough information, including the brochures and posters. Responses to question $4 b$-navigation between exhibition markers-were considered low ( 3,7 out of 5); perhaps because printed media was required for navigation.
For the last question in this section, regarding the duration of the @ Rkademi experience, the vast majority of users (71\%) felt that the exhibit and AR experience should be permanent. Responders felt that this AR environment should be designed as a permanent experience that could constantly be developed and refreshed.

\section{Thoughts on Current Conservation Issues of the Heritage}

In parallel with previous findings, the participants' level of interest with this space and heritage and the responses to the question of how effective the experience is in constructing or supporting these views are positive. The assessment shows that the users benefited from this experience, and it helped shape their views regarding conservation. The positive responses to question $4 \mathrm{f}$-would the participants would like to use AR for other purposes - reinforces this finding.

\section{Expert Review}

The expert review panel's primary concern was whether the experience, and especially the exhibition sections, communicated clear and transparent information about the heritage of the site. One area where this came into question was in the models of the current and former state of Mimar Sinan Hall (the model of its former state was created from old photographs). In the presentation of the models, to prevent possible tracker misalignment, the interpretation of the present situation was in white, while the digital visual reconstruction of its older state was shown in yellow, with the ceiling plan photo added in black and white. Reviewers pointed out that, in these experiences, the visualization can create a misleading perception of old/new and existing and evidence-based interpretations. It is necessary that in the future the methods and display techniques used should be carefully designed to ensure that this distinction is made clear and to prevent potential interpretation problems (Figure 5, Figure 6).

\section{Diversity of Mediums}

Another issue discussed by the expert 
review panel was that the information was scattered across different mediums. Therefore, the panel recommended that the supporting texts and plans should be arranged in such a way that they can be reached through the AR interface. This critique by the panel overlapped with the results of the questionnaire. They also advised that we find ways to guide users to the exhibition locations and navigate between them without the brochures and the poster, a critique also supported the questionnaire results.

Another proposal was to explore the possibility of interaction in the AR experiences. This could not be accomplished because of the lack interactivity options currently available on mobile platforms; audio and visual interactions were limited for the same reason.

Parallel to these criticisms, the review panel suggested it would be appropriate to investigate the gamification of the evaluation system and to add task performance evaluation. It should be noted that while possible gaming scenarios are important in terms of activating imagination and triggering spatial and cultural learning, it is important to ensure that gamification does not contradict the purposes of presentation.

It is a common behaviour that two or more people share the device or comment on the narrative along with the experience. This behaviour has an effect generally a positive contribution that helps users benefit from another's point of view. In order to measure the contribution of group visits versus individual visits for the transmission of social-cultural information, it is necessary to measure and assess the multi-participatory visits.

It is also important to determine the degree of interactivity and immersivity of the experience. On way to gather this type of date is to observe the instantaneous reactions that the user gives in the moment.

Discussed below are the conclusions regarding the development of the application in the light of the user experiences and evaluations.

\section{Suggestions for Developing the Application:}

- In practice, the information provided in different environments and media should be consolidated; wherever possible, the entire environment should be made available and accessible within the AR environment.

- Alternative interpretations should be presented, as should the voices and views of the people who took part in the architectural transformations. Providing multiple viewpoints will contribute to the understanding and protection of the cultural heritage values of this site.

- In future presentations, the changes in the surroundings should also be included and fit into the setting. Because the double palace buildings are in an urban area and cannot be considered separately from their surroundings, the urban transformation of the city should be included in the content.

- It should be ensured that the display can be customized according to user selections. Different heritage scenarios, according to different user groups, could be provided. Methods of individualization should be included, such as inviting users to select areas of interest; users should also be able to connect to their social media accounts, if they wish, to help tailor the experience. This suggestion would strengthen the link between heritage and individuals and opens the door for other research in the field of big data and heritage.

- Finally, the implementation of the AR experience should be continuous. Necessary steps must be taken to make the practice sustainable. A lot of planning and work is required to make AR applications permanent, such as: creating a digital data repository or the merging with an existing repository, incorporating VR technologies and applications, and making the content and media up to date, accessible, transparent, 
etc. Although the AR environment provides a broad framework, other environments need to be explored and used in heritage communications. Making the exhibition and AR experience permanent will keep this knowledge accessible, aid in the long-term preservation of the architectural heritage, ensure continuous engagement with stakeholders, and bolster the community's shared urban memories

\section{Suggestions for Improving the Evaluation:}

Interaction should be increased and gamification options should be explored. An interactive and bi-directional infrastructure, which can also support mission performance assessments, would allow for the continuous evaluation of outputs and the development of the AR environment.

Following the evaluation of the user surveys, it was decided that the following questions and methods should be added to clarify certain topics not covered effectively in the evaluations:

- The extent to which the content is remembered by users; this can be measured by post-experience surveys.

- Plan on follow-up evaluations that can be carried out on subsequent visits of the same participant, and monitor changes in his/her views.

- The need to sample from the user population from outside architecture and its related fields which accounts for a large part of the participant profile. A more diverse sample would allow for more precise decisions on perceptibility of digital environments and susceptibility to threedimensional environments.

\section{CONCLUSION}

The @Rkademi project and evaluation created a communication opportunity for discussions about space, heritage and conservation between participants and experts. Throughout the study, the process evaluation itself helped to clarify the "question posed," to suggest improvements in usability and to communicate the message and values of the heritage.

The questionnaire, therefore, can be considered as important not only as an evaluation of the application and the environment but as an opportunity to direct participants' attention to specific parts of the experiences, therefore helping to communicate the significance of the place. In order to construct a better interface for communication, both the questionnaire and the assessments should be carried out simultaneously in the environment and throughout the AR experience.

\section{ACKNOWLEDGEMENTS}

This study is based on research fund granted by Mimar Sinan Fine Arts University Scientific Research Project Directorate (Binan et al. 2014). We would like to thank the jurors, Prof. Dr. Can Binan, Prof. Dr. Salih Ofluoğlu, Prof. Dr. Zeynep Aygen and Prof. Dr. Leman Figen Gül, for taking part in the expert panel with the researchers. 


\section{References}

Beacham, R., Niccolucci, F. \& Denard., H., 2009. The

London Charter for the Computer-Based

Visualisation of Cultural Heritage, Available at:

http://www.londoncharter.org/.

Binan, D.U., Töre, T. \& Kut, S., 2014. 2013-12 Mimari

Koruma Alanında Artırılmış Gerçekliğin

Kullanımı ve Değerlendirilmesi Mimar Sinan

Güzel Sanatlar Üniversitesi Örneği Bilimsel

Araştırma Projesi Raporu, İstanbul.

Champion, E., 2015. Defining Cultural Agents for Virtual

Heritage Environments. Presence: Teleoperators

and Virtual Environments, 24(3).

Champion, E., 2011. Playing with the Past, London:

Springer London. Available at: http://link.springer.com/chapter/10.1007/978-1-84996-501-9_6

[Accessed September 30, 2014].

Champion, E., Bishop, I. \& Dave, B., 2012. The Palenque

Project: Evaluating Interaction in An Online

Virtual Archaeology Site. Virtual Reality, 16(2),

pp.121-139.

Dünser, A. \& Billinghurst, M., 2011. Evaluating Augmented Reality Systems. In Handbook of Augmented Reality. Springer Science + Business Media, pp. 289-307. Available at: http://link.springer. com/10.1007/978-1-4614-0064-6.

Pendit, U.C., Zaibon, S.B. \& Abubakar, J., 2014. User Experience on Enjoyable Informal Learning via Mobile AR : Development and Evaluation International Journal of Interactive Digital Media, 2(2), pp.29-34.

Portalés, C., Lerma, J.L. \& Pérez, C., 2009.

Photogrammetry and augmented reality for cultural heritage applications. The Photogrammetric Record, 24(December), pp.316-331. Available at: http://onlinelibrary.wiley.com/doi/10.1111/j.14779730.2009.00549.x/full [Accessed June 9, 2013].

Pujol, L. \& Champion, E., 2012. Evaluating presence in cultural heritage projects. International Journal of Heritage Studies, 18(1), pp.83-102.

Töre, T., 2017. Mimari Koruma Bağlamında Artırılmış Mekân Uygulamalarının Kullanımı ve Değerlendirilme Ölçütleri “@Rkademi” Uygulamast. Unpublished Phd Thesis, Restorasyon Yenileme - Koruma Programı, MSGSÜ.

Töre, T., Binan, D. \& Kut, S., 2014. Uses of Augmented Reality for Architectural Conservation Case of Msfau Findikli Campus Example. In Heritage and Landscape as Human Values. ICOMOS Italy, pp 470-474. 